\title{
The Thought Pattern of Aceh's Teungku Dayah in the Development of Islamic Madani
}

\author{
Muntasir A. Kadir, MA ${ }^{1, *}$ Muhammad Aminullah, MA ${ }^{2,}$ Iskandar Zulkarnaen ${ }^{3}$ \\ ${ }^{1}$ Lecturer in Political Science, Faculty of Social and Political Sciences, Malikussaleh University, Lhokseumawe \\ ${ }^{2}$ Lecturer at the Faculty of Da'wah and Communication at IAI Al-Aziziyah samalanga \\ ${ }^{3}$ Lecturer in Political Science, Faculty of Social and Political Sciences, Malikussaleh University, Lhokseumawe \\ *Email: muntasir@unimal.ac.id, aminullahtengku@gmail.com, iskandar.zulkarnaen@unimal.ac.id
}

\begin{abstract}
This research is important study to understand the thought pattern of Aceh's Teungku Dayah in the effort to develop an Islamic madani in Aceh. This thought pattern is always developing every time, from the first to the present generation. As for the media that are used, the majority are very involved in the dayahs, apart from a number of other media, such as tariqat, books, cultural arts and technology, Islamic madani is the hope of all people, due to being able to live well and peace with everyone. In this case the researcher needs to see clearly about the Teungku Dayah thought patterns that were developed to the people of Aceh in realizing the values of Islamic madani. This research is a qualitative research, using descriptive-analysis method, to answer the problematic development of the thought pattern of Teungku Dayah in the community in Aceh to the efforts of developing an Islam madani. The theory used is the theory of publication and theory of thought, which aim is to find the right thought patterns. This research was conducted through in-depth observations and interviews conducted by the researchers themselves. The results of the study are the patterns of thought carried out by teungku-teungku dayah into local culture in Aceh through strong religious education. This pattern is most important in community coaching. There are also lecture patterns which discussed, to answer all problems that develop in society. The goal is the message of Islamic teachings can be distributed evenly to all people. The findings in this study are that religious education development through dayah is one of the most influential local cultural media in society in Aceh. Based on an epistemological review of the development of Islamic thought which carried out through education is a good procedure in the field of knowledge theory. Because science can solve problems. Applying this pattern all people in Aceh have the Islamic knowledge, so that all can live properly, peacefully and safely and in accordance to Islamic teachings.
\end{abstract}

Keywords: Pattern, Thought, Teungku Dayah, Islam, Madani

\section{INTRODUCTION}

Islam can be developed through Da'wah, so da'wah can be defined as an activity that is carried out consciously by a person or group in order to convey Islamic teachings to others so that they are accepted and carried out properly to achieve happiness in the world and the hereafter. (Amin, 2009) Besides that, da'wah is a process of saving people from various problems that are detrimental to life in order to uphold justice, increase welfare, promote equality and achieve happiness with the pleasure of Allah (Enjang AS, Aliyudin, 2009).
The history of Islam entering Aceh was a blessing from the success of preaching developed by foreign preachers who entered Aceh. However, it should also be understood that the preachers have varied professions, either as traders or as nomads. His knowledge also includes fiqh and Sufi experts. The preachers were not from the military, as was the case in Spain. (Arnold, 1979)

The da'is use a persuasive approach to adapt well to the community and use a social approach. The message of preaching is developed through the behavior and manners of wise associations in society. This approach 
is one of the factors for the success of preaching in Aceh. can be seen in the theory of Thomas W. Arnold, saying that Islam entered the archipelago using a persuasive approach, namely utilizing their higher intelligence and civilization for the benefit of da'wah, not by violence "the sword as a means of da'wah." (Arnold, 1979) However, the fact that has developed now seems to have formed a doctrine in the delivery of Islamic teachings.

The success factors are important to be studied, to find a pattern or basic reference as a pattern of thought carried out by preachers in carrying out this da'wah, so that it becomes a guide for preachers to be applied in their da'wah activities. If it is seen from the cultural literature, that the phenomenon of the life of the Acehnese people, in fact they are not separated or are no longer isolated from da'wah messages either verbally, in writing or in symbols. The purpose of conveying this message is to make people aware of bad behavior and traits so that they want to do it in accordance with true Islamic values, even though all these expectations have not been maximally achieved.

This study is in the social-communication field with the scope of study referring to the information diffusion (Rakhmad, 1997) communication research model with discussion items including innovation in disseminating information about ideas and messages, media instruments and the implications of the value of communication patterns to the local public. The focus of this study is on Teungku Dayah's mindset in developing Islam into local culture in Aceh. The relevance of this study is to respond to an academic thinking model that makes philosophy a way of seeing phenomena, so that the presence of study results will contribute to providing these demands. Meanwhile, the significance of this study lies in the contribution to building socio-religious studies in society in Aceh.

The author needs to reiterate that the focus of this study is about the mindset of Teungku dayah in developing Islam into local culture in Aceh. Therefore, in making the research formulation, the writer dialogues two phenomena of publication patterns into local culture, namely between the pattern of publication of Islamic teachings into local culture in Aceh and an epistemological review of Teungku Dayah Thought in Aceh. The existence of Islam in Bireuen Regency is inseparable from the messages of 'Islamic da'wah published by religious elites with a certain pattern, based on the perspective of the preaching pattern they understand. This is evidenced by the presence of a number of dayahs and other educational instruments as a reflection of the existence of the Teungku dayah mindset in developing Islam to local communities. Therefore, the religious elite occupies an important position in publishing Islamic teachings to the local community.
In fact, it is known that the pattern of publications to convey da'wah information to the public is always carried out by religious leaders and intellectual figures, there are both firmly and self-awareness. The media used for conveying information are electronic media, print media, pulpit media and through formal and informal discussions using the information diffusion model. Publication patterns like this are expected to convey da'wah messages to the public, so that Islamic law is expected to be practiced in everyday life.

Likewise, the existence of dayahs in Aceh is one of the patterns of information delivery carried out by teungku-teungku dayah (dayah leaders). (Kurdi, 2008) This kind of pattern has been able to educate and give birth to da'wah cadres who will take part in society to convey the teachings of Islam. Some of the cadres who left the dayah also established their own dayah. as an effort to continue the role of the teacher. The proof is that there are many dayahs that have developed in Aceh. As happened at the MUDI Mesjid Raya Samalanga dayah, it has given birth to many da'wah cadres so that many alumni have established their respective dayahs and the name Al-Aziziyah is written at the end of their name.

Teungku dayah's mindset in the development of Islam which is carried out by establishing a dayah, so far most of them are still not as optimally coordinated as possible, especially in the field of leadership management. It can be proven that most dayahs who were advancing when their leaders died, dayahs also became degenerate, this factor was largely due to a pattern of dayah leaders that had not succeeded in educating their cadres specifically in the field of leadership management who could replace their positions. The effect was the number of dayahs that developed in Aceh, but very few of them lasted for several periods. With this fact, it is necessary to revisit how Teungku dayah's mindset is in the development of Islam carried out in local culture in Aceh. How is the epistemological review of the Teungku dayah thought pattern in the development of Islam carried out in Aceh.

\section{LITERATURE REVIEW}

In this literature review, the researcher raised several literatures. Considering that there have been many works produced by a number of experts in the field of Islamic development thinking with various approaches, an epistemological approach will be very possible to be developed in seeing the thought patterns of Teungku Dayah in the development of Islam carried out in Aceh. Likewise regarding some of the literature on the dayah, because in this study the dayah was used as one of the Islamic publication media in Aceh.

Among a number of literatures related to the study of philosophy is the Philosophical Research Methodology by Anton Bakker which discusses the method of philosophical research, as well as the 
explanation of the benefits of philosophical research and philosophical research models. The focus point of this research is on philosophical research models using the hermeneutic method and putting aside the scientific style that is based on the exact methodology. (Bakker, Metodologi Penelitian Filsafat, 1990)

Other articles are Philosophy of Social Research and Social Research Methods written by Ida Bagoes Mantra. This book describes philosophical research methods with respect to social phenomena and the form of philosophical research frameworks. The method used in this book is a phenomenological method that focuses on explaining the meaning of a reality, not based on predictions. An important topic in this paper is the process of survey research to find a true reality. (Mantra, 2008).

Next is the Philosophy of Science: an analysis of the workings of the sciences written by C. Verhaak. This book explains how science works, the certainty and truth of a science and the development of the epithemology of science in modern times. The discussion uses a thematic method by presenting the assumptions of several figures or schools of thought that are somewhat closer to historical. This book will help researchers to understand the issues surrounding the theory of truth, certainty and belief in how science works. (Verhaak, 1995)

Similar writing is the Epistemology of Philosophy of Knowledge written by Kenneth T. Gallagher and translated into Indonesian by P. Hardono Hadi. This book explains the main points of epistemology, epistemological approaches, knowledge of the existence and essence of social and historical truth, also discusses the philosophy of science and moral experience which is the result of the adaptation of human value consciousness with behavioral orders. (Hadi, 2001)

Another book is Communication Research Methodology written by Deddy Mulyana. This book discusses examples of qualitative research using a practical approach. In addition, it also distinguishes between forms of qualitative research with quantitative research. The discussion explains the form of communication development in Indonesia in various aspects, from communication in the lower community to the form of communication in the upper community. (Mulyana, 2007)

Meanwhile, Jalaluddin Rakhmat wrote Communication Research Methods: equipped with examples of statistical analysis. The book describes the concepts, methods, techniques and models of communication research. The most important discussion in it is about communication research methods, which is to provide an overview of communication models such as the information diffusion model which is the author's basic reference in conducting research on communication patterns. (Rakhmad, 1997)

Related to the Da'wah Science Methodology written by Andy Dermawan and his friends, the book explains the ontology, epistemology and axiology of the science of da'wah. In addition, there is also a discussion regarding the psychological foundation of da'wah science. This book study has a normative reference and uses a historical approach to explain the basis for the practice of da'wah carried out by the Prophet Muhammad as a source of early development of da'wah. The theory about the development of epistemology in this book can develop the science of da'wah from a psychological perspective in order to explain the ideal transformation efforts, mental conditions and behaviors contained in the human psyche so as to give birth to a discipline in the field of da'wah. (Dermawan, 2002)

Another book in line is the Da'wah Science Design of Ontological, Epistemological and Axiological Studies, written by Muhammad Sulthon. This book explains the thought of da'wah in philosophical studies which includes aspects of axiology, ontology, epistemology and dimensions of da'wah in Islam. The explanation presents the science of da'wah in a comprehensive direction, namely presenting the science of da'wah applied which talks about 'cultural, political and economic preaching. The method used is a schematic philosophical approach to the theories of da'wah. (Sulthon, 2003)

Meanwhile, Abdullah, in his book Insights Da'wah Epistemological Studies, Conception and Da'wah Applications, explains in general about the science of da'wah which is related to Islamic teachings in social reality as an objective approach. In addition, he also put forward a number of important theories that must be understood by the preacher. Therefore, the book develops the concept of da'wah epistemology as the basis for how to apply the science of da'wah. (Abdullah, 2002)

The literature that discusses dayah issues, as written by Hasbi Amiruddin in the book Looking at the Future of Dayah in Aceh, discusses the pattern of education in dayah starting from the curriculum system, the management that develops in dayah and the role of dayah alumni in the development of Islamic syar'at. The method of discussion in this book is descriptive only by using a phenomenological approach, while in its discussion there is no epistemological study of the phenomena in the dayah. So this book is necessary to look at the phenomenon of the development of education in dayah,(Amiruddin, 2008) as an effort to enrich the literature on dayah in this study.

\section{THEORETICAL FOUNDATION}

\subsection{Publication Theory}

Publication theory in this research is important to use and to find the form of delivering information on Teungku dayah's thoughts in the development of Islam carried out in Aceh. Publication theory is divided into two forms, namely da'wah and communication. Publication theory which is the delivery of spiritual information in this study is called da'wah theory, while the general theory is called communication theory.

\subsubsection{Da'wah Theory}

This theory explains the importance of da'wah as a pattern of delivering information. Talking about da'wah is a discussion related to religion, but the da'wah in this discussion is specifically the theory of da'wah. Da'wah according to A. Hasjmy is to invite other people to 
believe in and practice Islamic aqidah and syari'at as previously done by the preachers themselves.(Hasjmy, 1984) The da'wah in the theory of Enjang and Aliyudin is to invite people to the path of Allah as a whole both orally, in writing and in deeds as Muslim efforts to realize Islamic values. (Enjang AS, Aliyudin, 2009)

Meanwhile, Wahyu Ilaihi explained that preaching is an effort to influence people to follow Islam.(Ilaihi, 2010) From these two theories, it can be understood that the da'wah of Islam is a task that must be done by Muslims themselves, so it is not permissible for nonMuslim to do 'Islam to call people to Islam.

In a philosophical view, da'wah is a science that studies critically and deeply about da'wah and the purpose of 'da'wah. It takes a process of communication, transformation of Islamic teachings and values to change beliefs in someone who is Muslim. As for da'wah in the view of epistemology, in this study the author uses the theory of da'wah epiatemology developed by Yusny Saby, namely formulating procedures for appeals related to beliefs and attitudes of preachers to mad'uw who do not have the same perception.(Saby, 2000) In this study, the epistemological review developed by Yusny Saby is important, to find basic concepts about the technique of applying the Teungku dayah thought pattern in the development of Islam practiced in Aceh.

\subsubsection{Communication}

Communication is closely related to da'wah, but communication of studies is more general in nature. The communication theory according to Claude Hennon and Warren Weaver, quoted by Mohammad Zamroni, is the delivery of information, ideas, feelings, expertise through the use of words, pictures, shapes, graphics and others. Meanwhile, according to Harold Laswell's theory, also quoted by Mohammad Zamroni, communication is a process of conveying by communicators to communicants through media or channels that have an effect on the communicant.(Zamroni, 2009) From these two theories, it can be understood that communication is the delivery of information carried out by one person to another so that it influences the attitude and mindset (communicant).

The theory is not much different as defined by Wahyu Ilaihi, namely the process of delivering messages by communicators to communicants through the media which have certain consequences.(Ilaihi, 2010) Shannon and Weaver in B. Aubrey Fisher explained that communication includes all procedures both to seduce, persuade and share feelings through one's thoughts in order to influence others.(Fisher, 1986) So communication cannot be separated from one's life. Communication is a necessity in life to establish social relationships in the community. It is through this communication that people get to know each other at the local, national and international levels.

As for the difference between communication with preaching, it can be understood that communication is only a process of delivering information reciprocally with the aim of getting new news. Meanwhile, preaching is an effort to influence other people in a good way. The da'wah performer must have more knowledge than the recipient of the da'wah, so that it becomes new information for the recipient of the message.

\subsection{Islamic thought}

He study of thought cannot be separated from the development of a teaching it develops. Islamic thought is the development of teachings developed by thinkers from Islam itself. Previously, it was necessary to review the meaning of Islam. Islam is one of the divine religions that comes from Allah, the origin of the naming of Islam has been mentioned by Allah Himself in al-Qur'an surah Ali Imran verse 19 which explains that "Truly, religion with Allah is only Islam."

According to Jirhanuddin, Islam is a religion from Allah that was revealed to the Prophet Muhammad to be conveyed to all humans.(Jirhanuddin, 2010) It can be understood that Islam is a religion for all mankind, Islam is universal which does not differentiate between race and race and nation and nation in order to become a place of peace for all humans. This concept is not wrong if Islam is called rahmatan li al-'alamin.

Jirhanuddin explained that the thoughts on the core principles of Islamic teachings only revolve around three problems, namely aqidah, syari'at and morals. (Jirhanuddin, 2020) This view can be concluded that the three core points are the initial guidelines in living the harmony of Islam. Islam has regulated the relationship with God, the relationship with each other and the relationship with the universe. These three basic points are used as a method for living the relationship.

According to Muhammad Tholhah Hasan, Islam is divided into three areas, namely Islam as a teaching, Islam as a community and Islam as a movement. In this view, Islamic thought developed from the field of Islam as a teaching, because in that field it describes the knowledge of kalam, fiqh and tasawuf. (Hasan, 2005)

The theory of thought that the writer adopts here is the theory of reactualization proposed by Munawir Sjadzali, (Sjadzali, 1995) namely the theory of adapting Islam to the culture of society that has prevailed in an area according to its benefit. This theory is used to find out why Islam was published doctrinally in Aceh, whether the form of thought was a culture that developed in that society, so that the culture of thought was also influenced by the pattern of publication of Islamic teachings. This study investigates Islamic thought according to the theory developed by Nurcholish Madjid and Munawir Sjadzali. This thinking model is used for research on the development of Islam in Aceh.

Islamic thought has been able to shape human ideology towards a belief which is very much feared to be denied. This thinking is carried out in society in Aceh. The pattern of publication that is carried out is the use of media that are developing in Aceh such as books, banners, jum'atan bulletin and so on, to become evenly and thoroughly the spread of his teachings to all levels of society. The dayah is one of the most influential media in Acehnese society. 
Of all the theories used in this study, the authors make it a publication theory of Islamic doctrine. The form of the theory of publication of Islamic doctrine is as shown below.

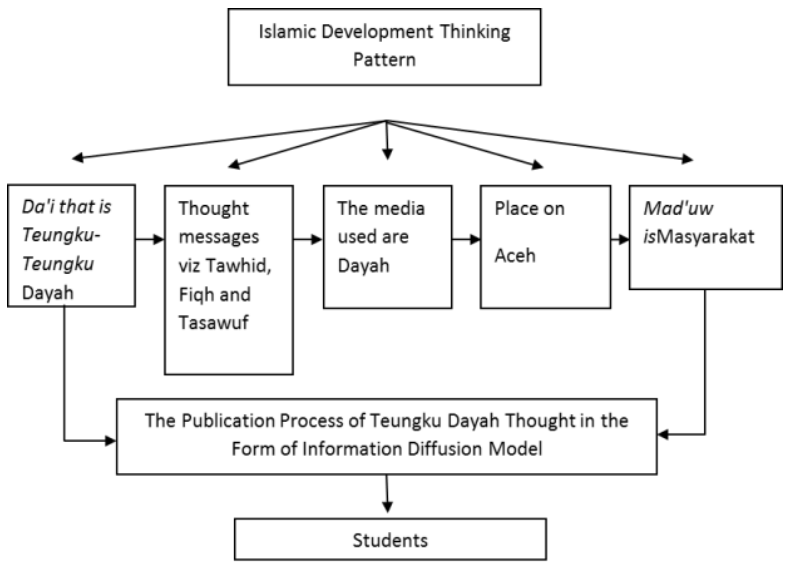

Figure 1 The theory of the publication of Teungku Dayah's thought in the development of Islam

\section{RESEARCH METHODOLOGY}

This research is a qualitative research using the descriptive-analysis type which aims to provide answers to the problems of instructional materials in the field of Islamic development thinking and to identify problems or to examine prevailing conditions and practices. (Rakhmad, 1997) This research will explore the philosophy of da'wah through an epistemological review of the Teungku Dayah thought pattern in the development of Islam carried out in Aceh. Therefore, this research will use the theory of da'wah epistemology, publication theory and Islamic doctrine theory to find the pattern of publication of Islamic thought through indepth observations and interviews conducted by the researchers themselves.

This study will also look at practical cases of communication with a focus on the teungku-teungku dayah communication model in Aceh, especially in the MUDI dayah Mesjid Raya Samalanga, Bireuen Regency. In conducting the research, the researcher used a phenomenological (Machfudz, tt) line of thought as a basis for compiling a number of general provisions regarding the values held by the dayah community and in finding the uniqueness of their perceptions and thought organizations about Islamic doctrine. While the construction of this research uses calculus-emic (Muhajir, 1996) in the sense that the construction of this research will be examined in the perspective of the informants themselves and the findings of documentation.

The domain of this research is classified into the field of social studies with the scope of the study of communication models, while the focus of the research is how Teungku Dayah's thinking pattern in the development of Islam is carried out in Aceh. At least this study is also related to a historical perspective to see the development of the dayah and its figures from time to time.

\section{RESEARCH FINDINGS}

\subsection{The Thought Of Teungku Dayah In The Dakwah Pattern \\ Teungku Dayah's thought in the preaching of this} research explains the patterns carried out by the ulama figures in Aceh in publishing Islamic doctrine to society. The da'i referred to in this research is teungku-Teungku Dayah (also known as Ulama Dayah) which is considered influential and has great potential in Aceh.(Abdullah, 1996) Apart from scholars, researchers also include academic figures with educational backgrounds as dayah alumni. The scholars who serve as the existence of publication figures in this study include Tgk. H. Hasanoel Bashry HG (Abu MUDI), Tgk. H. Yusuf A. Wahab, Tgk. H. Marhaban H. Adnan (Waled Bakongan), Tgk. H. Nuruzzahri Yahya (Waled Nu),

The Islamic development mindset developed by Sheikh Abu H. Hasanoel Bashry HG is primarily in the field of Islamic education. Dayah is one of the most appropriate preaching media to convey Islamic teachings in Aceh. The idea of education is that dayah is a traditional educational institution that specializes in understanding Islamic teachings. The educational development expected by Sheikh Abu H. Hasanoel Bashry HG is based on the results of the interview that it must be in accordance with the times. It is hoped that the development of Islamic thought through dayah education must be more advanced, so in MUDI an Islamic college was established called the Al-Aziziyah Islamic College (STAI Al-Aziziyah). Apart from that, he always hopes that MUDI alumni who have established their respective dayahs to open schools, at least equal to SMP. (Interview with Hasanoel Bashry)

From some of these discussions, it can be understood that several patterns for publishing Islamic doctrine have been carried out by Tgk. H. Hasanoel Bashry HG, to the community is the best pattern in community service, to accommodate all problems that arise in society. Likewise with all the hopes that Tgk. H. Hasanoel Bashry HG, so that people understand Islam correctly and can worship in the right way. With the existence of religious knowledge, society is not easy to be profiled on issues that can divide unity in society.

The pattern of thought in the development of Islam put forward by Tgk. H. Yusuf A. Wahab. Tgk. H. Yusuf A. Wahab dayah must be able to compete with the progress of the times, so dayah alumni must actively preach not only through recitation and lecture on the pulpit, but must be active as priests in scientific discussion forums. (Interview with Yusuf A. Wahab) Besides that, Tgk. Yusuf A. Wahab, really hopes that dayah can be developed by its own economic resources. If dayah has its own economic resources, it can live forever. This is due to the custom of dayahs in Aceh when the leader dies, the education in the dayah begins 
to decline. This factor is because the economy of teachers who teach is not guaranteed. To anticipate these problems, Tgk. H. Yusuf and other dayah figures established the Dayah Bersaudara Foundation (YADARA). YADARA is engaged in business economics. Now it has succeeded in establishing a drinking water factory located in Bate Iliek Samalanga.

The pattern of thinking in the development of Islam carried out by Tgk. H. Marhaban H. Adnan (Waled Bakongan), namely the pattern of community development through education, accompanying government policies or Friday sermons, whose purpose is to anticipate problems that cause conflict in society and the most important pattern is to do da'wah bi althings.( Interview with Marhaban Adnan) " This pattern is very influential in guarding and assisting the government in making policies to guard the community well.

Meanwhile, the Islamic thought pattern developed by Tgk. H. Nuruzzahri Yahya (Waled Nu), who developed the dayah of Ummul Ayman in 1990, took part in educating abandoned orphans who were victims of conflict or others. Then apart from that, Waled $\mathrm{Nu}$ is very active in guiding the community in terms of worship. The goal is that activities can be done simply and worship can be done perfectly. Perfection of worship has an effect on serenity in life. Every action that you want to do, is always based on a strong religion. (Interview with Nuruzzahri)

From some of the discussions above about the existence of thought publications figures in the development of Islam, it can be concluded that they agree on community development through religious education. Apart from that they also have their own patterns of fostering society in Aceh, to lead to a better society. The pattern of publication that they reflect on society can serve as a guide for discipline in life, both in education and in the daily interactions of fellow citizens and forming an Islamic society.

\subsection{Epistemological Approach To The Thinking Pattern Of Teungku Dayah Aceh In Islamic Development}

In this discussion, the researchers explain the development of teungku dayah's thought publication patterns in the epistemological review that has been developed by Acehnese scholars. All of them have the same pattern, namely the pattern of fostering Islamic education, but the implementation system has its own characteristics. In their thinking education is the way to get knowledge. With the existence of knowledge it can open broad insights for the people in Aceh. Science can lead to truth. In the study of epistemology, it is necessary to see why the application of science is needed. In the Cecep Sumarna concept, science focuses on the theoretical aspects of a number of knowledge acquired and possessed by humans.(Sumarna, 2008) Science leads people to curiosity. Curiosity becomes knowledge, while knowledge is gathered by science to answer the problems of daily life faced by humans and is used in offering various conveniences to them.(Suriasumantri,
2007) Here it can be concluded that science for humans is likened to a tool to solve the various problems it faces.

Based on the concept of science, it is very suitable as the pattern applied by tengku-tengku dayah, namely giving religious knowledge to the people of Aceh is very important, to be able to answer and anticipate all problems that arise in society. In addition, the existence of knowledge can strengthen belief in life. As for the overall form of the paradigm of thought affiliation of tendencies, teungku-teungku dayah follows and develops the Ahlu Al-Sunnah wa Al-Jama'ah understanding which is related to the science of kalam following the Asy'ari and Maturidi ideologies, fiqih follows the Syafi'i and Sufism schools of thought. following the thoughts of alGhazali and Abu Junaid al-Bagdadi. This is done for uniformity in terms of worship in public places, such as mosques, musalla, mosque and menasah.

In this discussion, it can be concluded that the thought pattern of teungku dayah in the development of Islam into culture in Aceh is almost the same pattern developed by teungku-teungku dayah. They have their own patterns, but they all prioritize education patterns to teach religious knowledge to the public. Science which is developed based on the tendency of his thinking. In the epistemological review, all these patterns are carried out so that people can understand Islam as a whole.

\section{CONCLUSION}

Based on the research results, it can be concluded that

a. The Teungku Dayah Thought Pattern in the development of Islam can be carried out through dayah, tereqat, books or books, cultural arts and mass media. The tendency of thinking towards the Ahlu Al-Sunnah wa Al-Jama'ah sect is because it has very many followers and a legacy from its teacher. While the fiqh of the Shafi'i school of thought and Sufism on Al-Ghazali's thoughts were also mostly influenced by teachers.

b. The pattern of publication is carried out by teungku-teungku dayah into local culture in Aceh through religious education, namely using dayah as an educational medium. The dayah that is expected is a dayah that can adapt to the times, even in terms of curriculum and opening formal schools. Apart from that, the dayah teungku-teungku are trying to make dayahs that are large categories in Aceh can open ma'had 'ali (dayah manyang).

c. Based on the epistemological review of the pattern of thought in Islamic development conveyed through the pattern of fostering religious education is a good procedure in the field of theory of knowledge to develop knowledge to society. Education can form knowledge that is based on 
science. Science is a path of knowledge to the nature of truth.

\section{AUTHORS' CONTRIBUTIONS}

This research can be used as an initial description for other researchers, who want to know the concept of thinking of figures in Aceh.

\section{ACKNOWLEDGMENTS}

Thank you to the faculty of the Faculty of Social and Political Sciences, University of Malikussaleh who have organized the ICoSPOLHUM 2020 program. This program is very useful in the academic world to improve the quality of lecturers.

\section{REFERENCES}

[1] A. Hasjmy, Dustur Dakwah Menurut Al-Qur`an, Jakarta: Bulan Bintang, 1984

[2] A. Rani Usman, Etnis Cina Perantauan Di Aceh, ed. 1, Jakarta: Yayasan Obor Indonesia, 2009

[3] Abdullah, Wawasan Da'wah Kajian Epistimoligi, Konsepsi dan Aplikasi da'wah, cet. 2, Medan: IAIN Press, 2002

[4] Anas S. Machfudz, Makalah-Makalah Metodologi Penelitian, Jakarta: LIPI, $\mathrm{tt}$

[6] Andy Dermawan, Motodologi Ilmu Da'wah, cet. 1, Yogyakarta: Lembaga Studi Filsafat Islam, 2002

[7] Anton Bakker, Metodologi Penelitian Filsafat, Yogyakarta: Kanisius, 1990

[8] B. Aubrey Fisher, Teori-Teori Komunikasi, terj: Soejono Trimo, Bandung: Remadja Karya, 1986

[9] C. Verhaak, Filsafat Ilmu Pengetahuan Telaah Atas Cara Kerja Ilmu-Ilmu, Jakarta: Gramedia Pustaka Utama, 1995

[10] Cecep Sumarna, Filsafat Ilmu, cet.3, Bandung: Mulia Press, 2008

[11] Deddy Mulyana et all, Metode Penelitian Komunikasi Contoh-Contoh Penelitian Kualitatif Dengan Pendekatan Praktis, cet. 1, Bandung: Remaja Rosdakarya, 2007

[12] Deddy Mulyana, Metode Penelitian Komunikasi, Bandung: Remaja Rosdakarya, 2007

[13] Enjang dan Aliyudin, Dasar-Dasar Ilmu Dakwah Pendekatan Filosofis dan Praktis, cet. 1, Padjadjaran: Widya, 2009
[14] Ida Bagoes Mantra, Filsafat Penelitian dan Metode Penelitian Sosial, Yogyakarta: Pustaka Pelajar, 2008

[15] Jalaluddin Al-Sayuthi, Tafsir Jalalain, jilid 3, Indonesia: Al-Haramain, tt

[16] Jalaluddin Rahmat, Metode Penelitian Komunikasi Bandung: Remaja Rosdakarya, 1997

[17] Jirhanuddin, Perbandingan Agama Pengantar Studi Memahami Agama-Agama, cet. 1, Yogyakarta: Pustaka Pelajar, 2010

[18] M. Hasbi Amiruddin, Menatap Masa Depan Dayah Di Aceh, cet. 1, Banda Aceh: Yayasan Pena, 2008

[19] Mohammad Zamroni, Filsafat Komunikasi Pengantar Ontologis, Epistemologis, Aksiologis, ed. 1, Yogyakarta: Graha Ilmu, 2009

[20] Muhammad Sulthon, Desain Ilmu Da'wah Kajian Ontologis, Epistimologis dan Aksiologis, cet. 1, Semarang: Pustaka Pelajar, 2003

[21] Muhammad Tholhah Hasan, Islam Dalam Perspektif Sosio Kultural, cet. 3 Jakarta: Lantabora Press, 2005

[22] Muliadi Kurdi, Kajian Tinggi Keislaman, Nanggroe Aceh Darussalam, Banda Aceh: Biro Keistimewaan dan Kesejahteraan Rakyat, 2008

[23] Munawir Sjadzali, Kontektualisasi Ajaran Islam, cet. 1, Jakarta Selatan: IPHI dan Yayasan Wakaf Paramadina, 1995

[24] Noeng Muhajir, Metodologi Penelitian Kualitatif, Yogyakarta: Rake Sarakin, 1996

[25] Norman K. Denzin dan Yvonna S. Lincoln, Handbook of Qualitative Research, terj: Dariyanto, et all, cet. 1, Yogyakarta: Pustaka Pelajar, 2009

[26] P. Hardono Hadi, Epistemologi Filsafat Pengetahuan, cet. 7, Yogyakarta: Kanisius, 2001

[27] Samsul Munir Amin, Ilmu Dakwah, ed. 1, cet. 1, Jakarta: Amzah, 2009

[28] Taufik Abdullah (et. All), Agama dan Perubahan Sosial, cet. 1, Jakarta: Raja Grafindo Persada, 1996

[29] Thomas W. Arnold, The Preaching of Islam, terj. Nawawi Rambe, Sejarah Da'wah Islam, Jakarta: Widjaya, 1979

[30] Wahyu Ilaihi, Komunikasi Dakwah,cet. 1, Bandung: Remaja Rosdakarya, 2010

[31] Yusny Saby dalam buku A. Karim Syeikh, edt, Ilmu Dakwah Ditinjau Dari Berbagai Aspeknya, Banda Aceh: Fakultas dakwah IAIN Ar-Raniry, 2000 